\title{
PENINGKATAN AKTIVITAS DAN HASIL BELAJAR SISWA PADA PEMBELAJARAN IPA DENGAN PENDEKATAN KETERAMPILAN PROSES
}

\author{
Wayan Suana \\ Pendidikan Fisika, FKIP Universitas Lampung \\ Jl. Sumantri Brojonegoro No. 1 Bandar Lampung; e-mail: wsuane@gmail.com \\ Diterima: 2 Januari 2016. Disetujui: 5 April 2016. Dipublikasikan: April 2016
}

\begin{abstract}
This research aimed to: (1) describe the increase of students' activity in the skill-based process in science learning, (2) describe the increase of students' learning achievement in the skill-based process in science learning. This classroom action research has been conducted in three cycles with 29 students of VIIA Class of Junior High School (SMP) Dharma Bakti, South Lampung. Every cycle consist of planning, action and observation, and reflection. The data were collected using multiple choice test for learning achievement and observation sheet for students' activity. The results showed that process skill approach could increase students' activity and learning achievement of science from cycle to cycle. The average students' activity score from the first cycle to the third cycle were 62,1 (sufficient), 70,0 (sufficient), and 77,1 (active), respectively. The average students' learning achievement from cycle I to cycle III were 62,1 (sufficient), 65,2 (sufficient), 69,7 (good), respectively.
\end{abstract}

\begin{abstract}
Abstrak: Tujuan penelitian ini adalah untuk: (1) mendeskripsikan peningkatan aktivitas siswa pada pembelajaran IPA dengan pendekatan keterampilan proses, (2) mendeskripsikan peningkatkan hasil belajar kognitif siswa pada pembelajaran IPA dengan pendekatan keterampilan proses. Penelitian ini merupakan jenis penelitian tindakan kelas yang dilaksanakan dalam tiga siklus. Setiap siklus terdiri dari perencanaan, tindakan dan pengamatan, dan refleksi. Subyek penelitian ini adalah siswa kelas VIIA SMP Dharma Bakti Lampung Selatan yang berjumlah 29 siswa. Instrumen yang digunakan adalah lembar observasi dan soal pilihan jamak. Hasil penelitian menunjukkan bahwa pendekatan keterampilan proses dapat meningkatkan aktivitas dan hasil belajar kognitif siswa dari siklus ke siklus. Rata-rata nilai aktivitas siswa dari siklus I sampai siklus III secara berturut-turut adalah 62,1 (cukup aktif), 70,0 (cukup aktif), dan 77,1 (aktif). Adapun rata-rata hasil belajar kognitif siswa dari siklus I sampai siklus III secara berturut-turut adalah 62,1 (cukup baik); 65,2 (cukup baik); dan 69,7 (baik).
\end{abstract}

(C) 2016 Pendidikan Fisika FTK IAIN Raden Intan Lampung

Kata Kunci: aktivitas siswa, hasil belajar kognitif, IPA, pendekatan keterampilan proses

\section{PENDAHULUAN}

Dari hasil observasi dan wawancara langsung dengan guru mata pelajaran IPA yang mengajar di kelas VIIA SMP Dharma Bakti, diketahui bahwa rata-rata hasil uji kompetensi pada materi Besaran dan Satuan hanya 52,5, dimana sebagian besar siswa belum mencapai kriteria ketuntasan minimal (KKM) yang ditetapkan sebesar 60. Pembelajaran IPA di kelas tersebut juga didominasi oleh metode ceramah. Siswa menerima pelajaran dengan mencatat penjelasan dari guru serta dari buku cetak. Siswa kemudian diberi latihan mengerjakan soal-soal. Dominannya peran guru dalam pembelajaran membuat siswa sangat pasif bahkan terkesan malas saat belajar. Siswa sangat jarang diajak melakukan eksperimen, melakukan pengamatan atau berdiskusi. Dalam proses belajar mengajar di sekolah saat ini tidak atau belum memberi kesempatan maksimal kepada siswa untuk mengembangkan kreativitasnya, hal ini merupakan salah satu permasalahan yang menunjukkan 
rendahnya mutu pendidikan IPA. (Wuryastuti, 2008). Metode pembelajaran seperti itu diduga menjadi penyebab rendahnya hasil belajar kognitif IPA siswa.

Dalam pembelajaran, guru hendaknya melibatkan siswa secara aktif bukan sekadar mendengarkan dan mencatat penjelasan guru. Aktivitas tidak terbatas pada aktivitas fisik saja, tetapi juga aktivitas mental. Hal ini berarti bahwa dalam kegiatan belajar kedua aktivitas itu harus selalu dilakukan oleh siswa. Aktivitas sangat penting agar hasil belajar yang diperoleh siswa optimal. Hal ini sejalan dengan pernyataan Sardiman (2005: 95) bahwa belajar adalah berbuat dan sekaligus proses yang membuat anak didik menjadi aktif. Selain itu, sanjaya (2007: 132) juga menyatakan bahwa belajar adalah berbuat, memperoleh pengalaman tertentu sesuai dengan tujuan yang diharapkan.

Benyamin Bloom menyatakan bahwa ranah psikomotorik berkenaan dengan hasil belajar keterampilan dan kemampuan bertindak. Ada enam aspek ranah psikmotorik diantaranya gerakan refleks, gerakan kemampuan (abilities), kemampuan berpendapat (perseptual abilities), dan komunikasi (communications). Oleh karena itu, aktivitas siswa dapat dianggap sebagai hasil belajar ranah psikomotorik. Siswa dikatakan aktif jika dia melakukan kegiatan-kegiatan pembelajaran yang relevan dengan materi pelajaran yang disampaikan.

Salah satu pendekatan pembelajaran yang dapat diterapkan untuk meningkatkan aktivitas serta hasil belajar kognitif siswa adalah pendekatan keterampilan proses. Pendekatan keterampilan proses adalah pendekatan pembelajaran yang memberi kesempatan kepada siswa agar dapat menemukan fakta, membangun konsep-konsep, melalui kegiatan dan atau pengalamanpengalaman seperti ilmuwan (Kurniati,
2001: 11). Selain itu, pendekatan keterampilan proses adalah wawasan atau anutan pengembangan keterampilanketerampilan intelektual, sosial, dan fisik yang bersumber dari kemampuankemampuan mendasar yang pada prinsipnya telah ada dalam diri siswa (Dimyati \& Mudjiono, 2009). Dari kedua pengertian diatas, dapat disimpulkan bahwa pendekatan keterampilan proses adalah pendekatan pembelajaran untuk mengembangkan keterampilan intelektual, sosial dan fisik siswa dengan melakukan kegiatan belajar secara langsung dalam menemukan fakta dan konsep.

Pendekatan keterampilan proses dapat mengembangkan kemampuan berpikir siswa. Siswa menjadi aktif dalam menggunakan pikirannya untuk menemukan berbagai konsep atau prinsip dari suatu materi yang dipelajari. Seperti yang dikemukakan oleh Bruner (Hendrik, 2000: 14) bahwa dalam pembelajaran dengan pendekatan keterampilan proses, anak akan menggunakan pikirannya untuk memahami berbagai konsep atau prinsip. Keterampilan proses merupakan asimilasi dari berbagai keterampilan intelektual yang dapat diterapkan pada proses pembelajaran.

Keterampilan-keterampilan yang dikembangkan pada pembelajaran berbasis keterampilan proses adalah: (1) mengamati, yaitu keterampilan mengumpulkan data atau informasi melalui penerapan dengan indera berdasarkan kegiatan yang dilakukan. (2) menafsirkan, yaitu keterampilan untuk menganalogikan suatu eksperimen dengan konsep yang ada. (3) mendiskusikan, yaitu keterampilan untuk dapat bekerjasama tim untuk membahas permasalahan. (4) menganalisis, yaitu kemampuan untuk dapat menganalisis permasalahan berdasarkan keterampilan mengamati yang telah dilakukan. (5) menyimpulkan hasil penelitian, yaitu keterampilan untuk mengambil suatu ke- 
simpulan dari serangkaian kegiatan yang telah dilaksanakan setelah dilakukan analisis dan diskusi. (6) menerapkan, yaitu mengaplikasikan hasil belajar berupa informasi, kesimpulan, konsep, hukum, teori, dan keterampilan. (7) mengkomunikasikan, yaitu menyampaikan perolehan atau hasil belajar kepada orang lain dalam bentuk tulisan, gambar, gerak, tindakan, atau penampilan (Reviandi, 2008).

Adapun untuk pelaksanaan di kelas, pembelajaran dengan pendekatan keterampilan proses dirancang dengan beberapa tahapan yang dapat meningkatkan aktivitas dan hasil belajar siswa. Tahapan pembelajaran dengan pendekatan keterampilan proses menurut Dimyati \& Mudjiono (1999 : 49) dapat dibagi menjadi tiga, yaitu kegiatan pendahuluan (pemberian motivasi, apersepsi, dan penyajian fenomena), kegiatan inti (demonstrasi atau eksperimen), dan kegiatan akhir (penguatan materi dan penanaman konsep).

Hasil penelitian E. Rahayu dkk (2011) menyimpulkan bahwa dengan menerapkan pendekatan keterampilan proses dapat meningkatkan hasil belajar siswa. Selanjutnya Suciati (2011) mengungkapkan bahwa kesimpulan yang didapat dari hasil analisis data dan pembahasan adalah pembelajaran berbasis keterampilan proses sains memiliki keunggulan-keunggulan yakni selain memungkinkan peserta didik dapat terlibat aktif secara intelektual, manual, dan sosial yang dapat mengantarkan peserta didik untuk belajar secara bermakna dan dapat mengoptimalkan hasil belajar.

Berdasarkan uraian di atas maka tujuan penelitian ini adalah (1) mendeskripsikan peningkatan aktivitas siswa selama pembelajaran dengan pendekatan keterampilan proses, dan (2) mendeskripsikan peningkatkan hasil belajar ranah kognitif IPA siswa selama pembelajaran dengan pendekatan keterampilan proses.

\section{METODE PENELITIAN}

Penelitian ini merupakan jenis penelitian tindakan kelas dengan tiga siklus yang masing-masing siklus terdiri dari tiga tahapan yaitu perencanaan, tindakan dan pengamatan, dan refleksi. Setiap siklus terdiri dari dua kali pertemuan. Pertemuan pertama dan kedua berlangsung selama $2 \times 40$ menit. Adapun subyek pada penelitian ini adalah siswa kelas VIIA SMP Dharma Bakti Lampung Selatan yang berjumlah 29 siswa (13 lakilaki dan 16 perempuan). Kurikulum yang digunakan di sekolah tersebut pada saat penelitian dilaksanakan adalah kurikulum tingkat satuan pendidikan (KTSP).

Pada siklus I, materi pembelajaran adalah suhu dan pengukurannya, yaitu mengenai pengertian suhu, pengukuran suhu dengan termometer, prinsip kerja termometer, dan konversi suhu. Pada siklus II, materinya adalah pengukuran dan satuan, yaitu mencakup pengertian satuan baku dan satuan tak baku, pengukuran besaran pokok, dan pengukuran besaran turunan. Pada siklus III, materi pembelajarannya adalah zat dan wujudnya, yaitu membahas tentang pengertian zat, macam-macam wujud zat, kohesi adhesi, meniskus, dan kapilaritas.

Instrumen yang digunakan meliputi lembar pengamatan aktivitas siswa dan soal tes. Data yang dikumpulkan berupa data kualitatif, yaitu data aktivitas siswa, dan data kuantitatif, yaitu data hasil belajar kognitif siswa. Data aktivitas siswa per siklus adalah rata-rata aktivitas siswa dari setiap pertemuan. Aspek aktivitas belajar siswa yang diamati antara lain peran serta siswa dalam pembelajaran, mengerjakan lembar kerja siswa (LKS), bekerjasama dengan teman sekelompok, keaktifan siswa dalam diskusi, dan partisipasi siswa dalam demonstrasi/ eksperimen. Siswa dikategorikan "aktif" jika nilai 
aktivitasnya $\geq 75,6$. Jika $59,4 \leq$ nilai aktivitas $<75,6$ maka siswa dikategorikan "cukup aktif", dan jika nilai aktivitas siswa $<59,4$ maka dikategorikan "kurang aktif" (Memes, 2001: 36). Sementara itu, soal hasil belajar kognitif berbentuk pilihan jamak dengan empat pilihan jawaban tiap butir soal dan jumlah butir soal sebanyak 10 butir yang diberikan setelah berakhirnya suatu siklus. Apabila hasil belajar kognitif siswa $\geq 66$, maka dikategorikan baik, jika $55 \leq$ nilai siswa $\geq$ 66, maka dikategorikan cukup baik, dan nilai siswa $<55$, maka dikategorikan kurang baik (Arikunto, 2008).

Hipotesis tindakan dalam penelitian ini adalah dengan menerapkan pendekatan keterampilan proses pada pembelajaran IPA Kelas VII SMP pada pokok bahasan suhu, pengukuran, dan zat dan wujudnya akan meningkatkan aktivitas dan hasil belajar kognitif IPA siswa. Sejalan dengan itu maka indikator keberhasilan dalam penelitian ini dilihat dari adanya peningkatan atau kecenderungan peningkatan aktivitas dan hasil belajar kognitif IPA siswa dari siklus I sampai siklus III.

\section{HASIL DAN PEMBAHASAN}

Penelitian ini berlangsung dari tanggal 26 Juli - 10 Agustus 2012, dan dilaksanakan dalam tiga siklus. Setiap siklus terdiri dari dua pertemuan dimana masing-masing pertemuan berlangsung selama $2 \times 40$ menit. Pokok bahasan pada siklus I adalah Suhu dan Pengukurannya, yaitu mencakup pengertian suhu, pengukuran suhu dengan termometer, prinsip kerja termometer, dan konversi suhu dalam berbagai skala. Pokok bahasan pada siklus II adalah Pengukuran, meliputi pengertian satuan baku dan satuan tak baku, pengukuran besaran pokok, dan pengukuran besaran turunan. Selanjutnya pada siklus III, pokok bahasannya adalah Zat dan Wujudnya, yang mencakup pengertian zat, macammacam wujud zat, kohesi, adhesi, meniskus, dan kapilaritas. SMP Dharma Bakti menyelenggarakan kegiatan pembelajaran mulai siang sampai sore hari, dan setiap pertemuan pada penelitian ini dilaksanakan pada pukul 14.20 - 16.00 WIB.

Pada tahap perencanaan, dilakukan penyusunan silabus dengan pendekatan keterampilan proses, rencana pelaksanaan pembelajaran (RPP), LKS, dan penyusunan instrumen penelitian. Pada tahap tindakan dan pengamatan, guru peneliti melaksanakan pembelajaran dengan pendekatan keterampilan proses. Siswa dikelompokkan secara acak ke dalam enam kelompok, dan masingmasing kelompok terdapat lima siswa, kecuali satu kelompok yang anggotanya enam siswa. Selama pembelajaran, guru peneliti juga menilai aktivitas siswa. Pada akhir siklus, siswa diberi tes untuk mengukur hasil belajarnya selama 30 menit di luar waktu pembelajaran.

Data mengenai aktivitas siswa untuk setiap siklus yang dikumpulkan pada penelitian ini diberikan pada Tabel 1. Ada empat aspek aktivitas yang diamati, yaitu mengerjakan LKS, kerjasama dalam kelompok, peran serta siswa dalam pembelajaran, keaktifan dalam diskusi, dan partisipasi siswa dalam eksperimen. Tampak bahwa rata-rata nilai aktivitas siswa mengalami peningkatan dari siklus I sampai siklus III. Persentase siswa dengan kategori "aktif" juga meningkat tiap siklus seiring dengan penurunan jumlah siswa dengan kategori "kurang aktif". Data ini menunjukkan bahwa pembelajaran dengan pendekatan keterampilan proses dapat membuat siswa aktif. Pada pendekatan keterampilan proses, siswa diberi kesempatan belajar untuk menemukan fakta, membangun konsep-konsep, melalui kegiatan dan atau pengalaman-pengalaman seperti ilmuwan (Kurniati, 2001: 11). 
Tabel 1. Data aktivitas siswa tiap siklus

\begin{tabular}{lccc}
\hline \multicolumn{1}{c}{$\begin{array}{c}\text { Aktivitas } \\
\text { Siswa }\end{array}$} & Siklus I & $\begin{array}{c}\text { Siklus } \\
\text { II }\end{array}$ & $\begin{array}{c}\text { Siklus } \\
\text { III }\end{array}$ \\
\hline Aktif & $0 \%$ & $17 \%$ & $52 \%$ \\
Cukup Aktif & $72 \%$ & $76 \%$ & $48 \%$ \\
Kurang & & & \\
Aktif & $28 \%$ & $7 \%$ & $0 \%$ \\
Maksimum & 75 & 80 & 90 \\
Minimum & 45 & 55 & 65 \\
Rata-Rata & 62,1 & 70,0 & 77,1 \\
Kriteria & cukup & cukup & aktif \\
\hline
\end{tabular}

Secara keseluruhan, rata-rata aktivitas siswa pada siklus I tergolong cukup aktif dengan nilai 62,1. Aspek aktivitas yang masih rendah pada siklus I adalah keaktifan siswa dalam diskusi, bekerjasama dengan teman sekelompok, dan aspek peran serta siswa dalam pembelajaran. Sebagian besar siswa masih malu-malu menyampaikan pendapatnya dan kurang percaya diri dengan pendapat mereka sendiri sehingga pada saat mengemukakan pendapat, siswa tampak gugup. Siswa juga belum terbiasa bekerja dalam kelompok. Selain itu, peran serta siswa dalam pembelajaran juga masih kurang. Sebagian siswa cenderung kurang memperhatikan penjelasan guru dengan seksama. Siswa juga masih belum berani menjawab pertanyaan guru secara tegas. Belum baiknya aktivitas siswa pada siklus I disebabkan siswa belum terbiasa belajar dengan pendekatan keterampilan proses.

Pada siklus II, aktivitas siswa mengalami peningkatan sebesar 7,9 dibandingkan siklus I. Secara umum, selama proses pembelajaran pada siklus II siswa menunjukkan peningkatan aktivitas yang positif. Aktivitas siswa yang masih kurang adalah keaktifan siswa dalam diskusi. Siswa masih belum berani menyampaikan pendapatnya walaupun pendapatnya benar. Selain keaktifan dalam diskusi, aktivitas bekerjasama dengan teman sekelompok juga masih belum berkategori baik. Walaupun mengalami peningkatan, aspek ini masih harus terus diperbaiki oleh siswa. Siswa masih lebih banyak bekerja sendirisendiri. Hal ini kemungkinan disebabkan siswa masih belum terbiasa bekerja kelompok.

Pada siklus III, nilai aktivitas siswa mengalami peningkatan dari siklus II. Aktivitas bekerjasama dengan teman sekelompok dan aspek keaktifan siswa dalam diskusi mengalami peningkatan yang sangat signifikan. Peningkatan aktivitas siswa dalam bekerjasama dengan teman sekelompok disebabkan siswa terlihat kompak dalam mengerjakan tugas kelompok. Siswa yang tadinya masih bekerja sendiri-sendiri menjadi mau bekerjasama dengan teman sekelompoknya sedangkan peningkatan aktivitas keaktifan siswa dalam diskusi terjadi karena siswa sudah mulai berani mengemukakaan pendapatnya. Guru peneliti terus memancing siswa agar mau berpendapat ataupun bertanya. Selain itu, peningkatan aktivitas ini kemungkinan disebabkan juga karena siswa sudah mulai terbiasa dengan bekerjasama dan berdiskusi dengan teman sekelompoknya.

Sejalan dengan peningkatan aktivitas siswa pada tiap siklus, hasil belajar kognitif siswa juga mengalami peningkatan dari siklus I sampai siklus III, seperti yang ditunjukkan oleh Tabel 2. Dengan KKM 60, persentase jumlah siswa yang mencapai ketuntasan KKM mengalami peningkatan dari $69 \%$ pada siklus I menjadi $90 \%$ pada siklus III. Peningkatan hasil belajar kognitif siswa yang sejalan dengan peningkatan aktivitas ini sesuai dengan pendapat Uno (Rahayu dkk., 2011) bahwa semakin siswa terlibat dalam setiap kegiatan pembelajaran, semakin baik perolehan hasil belajarnya.

Tabel 2. Hasil belajar kognitif tiap siklus

\begin{tabular}{lccc}
\hline Keterangan & Siklus I & $\begin{array}{c}\text { Siklus } \\
\text { II }\end{array}$ & $\begin{array}{c}\text { Siklus } \\
\text { III }\end{array}$ \\
\hline Nilai maks. & 80 & 90 & 100 \\
Nilai min. & 40 & 40 & 50 \\
Rata-rata & 62,1 & 65,2 & 69,7 \\
Kriteria & cukup & cukup & baik \\
Ketuntasan & $69 \%$ & $83 \%$ & $90 \%$ \\
\hline
\end{tabular}


Pada siklus I, tidak hanya aktivitas siswa yang masih rendah, hasil belajar kognitif siswa juga belum berkategori baik. Rendahnya aktivitas siswa pada siklus I diduga turut mengakibatkan belum optimalnya hasil belajar siswa, seperti yang dinyatakan oleh Dimyati \& Mudjiono (2009) bahwa belajar memerlukan keterlibatan pembelajaran secara aktif. Rata-rata hasil belajar kognitif siswa pada siklus I adalah 62,1 dimana sebanyak 69\% siswa tuntas sedangkan $31 \%$ siswa belum tuntas. Konsep yang belum dipahami oleh kebanyakan siswa yaitu prinsip kerja termometer dan konsep konversi suhu dalam berbagai skala termometer.

Pada siklus II, mulai tampak adanya peningkatan hasil belajar kognitif siswa. Hasil belajar pada siklus II mengalami peningkatan 3,1 dari siklus I. Adapun konsep yang paling susah bagi siswa adalah membaca hasil pengukuran dengan jangka sorong. Konsep lain yang sulit adalah mengenai ketelitian jangka sorong. Siswa masih belum paham bagaimana cara menentukan ketelitian sebuah jangka sorong. Hal ini menandai bahwa siswa memerlukan waktu beradaptasi dengan pembelajaran dengan pendekatan keterampilan proses.

Pada siklus III, rata-rata hasil belajar kognitif siswa mengalami peningkatan dari siklus II sebesar 4,5 sehingga menjadi 69,7. Setelah melalui pembelajaran pada siklus I dan siklus II, tampak bahwa aktivitas dan hasil belajar siswa terus meningkat secara perlahanlahan. Konsep masih sulit dikuasai siswa pada siklus III adalah mengenai penerapan konsep gaya kohesi atau gaya adhesi pada bentuk tetesan air dan pada peristiwa meniskus.

Meskipun hasil belajar kognitif siswa terus meningkat, peningkatannya dapat dikatakan masih rendah. Pada siklus III rata-rata hasil belajar siswa masih di bawah 75. Selain faktor adaptasi siswa terhadap pendekatan keterampilan proses, faktor lain yang diduga turut berpengaruh adalah kemampuan awal siswa. Kemampuan awal siswa di sekolah ini memang kurang baik. Sebagai sekolah swasta yang berada di pedesaan, KKM yang ditetapkan untuk pelajaran IPA hanya 60. Untuk itu, pembelajaran IPA dengan pendekatan ini mestinya terus dilakukan, tidak berhenti sampai pada siklus III saja.

Melihat peningkatan aktivitas dan hasil belajar kognitif siswa pada penelitian ini, turut menguatkan pernyataan dari Subagyo dkk. (2009) bahwa pendekatan keterampilan proses penting sekali untuk diterapkan pada pembelajaran IPA karena melibatkan siswa untuk aktif dalam pembelajaran sehingga dapat meningkatkan hasil belajar siswa sesuai dengan tuntutan kurikulum. Pendekatan keterampilan proses dalam pembelajaran IPA beranggapan bahwa IPA terbentuk dan berkembang melalui suatu proses ilmiah yang juga harus dikembangkan pada peserta didik sebagai pengalaman yang bermakna yang dapat digunakan sebagai bekal perkembangan diri selanjutnya (Memes, 2000). Tidak hanya aktivitas dan hasil belajar, dengan mengembangkan keterampilan proses, sikap dan nilai-nilai juga dapat serta tumbuh dan berkembang. Dengan demikian, keterampilan proses menjadi roda penggerak penemuan dan pengembangan fakta dan konsep, serta penumbuhan dan pengembangan sikap dan nilai (Semiawan, 1992).

Hasil penelitian ini sejalan dengan penelitian Subagyo dkk. (2009) dan Rahayu dkk. (2011). Kesimpulan yang diperoleh oleh Subagyo dkk. (2009) adalah bahwa hasil belajar pemahaman konsep siswa dapat ditingkatkan melalui pembelajaran dengan pendekatan keterampilan proses pada pokok bahasan suhu dan pemuaian dengan kriteria peningkatan rendah. Pada penelitian Rahayu dkk. (2011), pembelajaran melalui pendekatan keterampilan proses 
yang dilakukannya telah memenuhi indikator ketuntasan klasikal sehingga pendekatan ini disimpulkan dapat digunakan sebagai salah satu metode untuk meningkatkan pemahaman siswa terhadap materi pelajaran.

\section{SIMPULAN DAN SARAN}

Berdasarkan hasil dan pembahasan di atas, diperoleh simpulan bahwa pembelajaran IPA yang menerapkan pendekatan keterampilan proses dapat meningkatkan aktivitas siswa dari siklus ke siklus. Pada siklus I aktivitas belajar siswa sebesar 62,1 dengan kategori "cukup aktif". Pada siklus II aktivitas siswa meningkat menjadi 70,0 dengan kategori "cukup aktif". Pada siklus III aktivitas siswa kembali meningkat menjadi 77,1 dengan kategori "aktif". Seiring dengan peningkatan aktivitas siswa, pembelajaran IPA yang menerapkan pendekatan keterampilan proses juga dapat meningkatkan hasil belajar kognitif siswa dari siklus ke siklus. Pada siklus I hasil belajar siswa sebesar 62,1 dengan kategori "cukup baik". Pada siklus II meningkat menjadi 65,2 dengan kategori "cukup baik". Pada siklus III meningkat lagi menjadi 69,7 dengan kategori "baik".

Maka dari itu, kepada para pendidik IPA ataupun Fisika, pendekatan keterampilan proses dapat digunakan sebagai alternatif dalam pembelajarannya agar mengaktifkan siswa serta meningkatkan hasil belajar aspek kognitifnya. Penerapan pendekatan keterampilan proses juga hendaknya dilakukan secara kontinue, tidak hanya dalam tiga siklus, agar hasil belajar siswa dapat optimal. Namun, pada penelitian ini, peneliti tidak melakukan penilaian secara spesifik terhadap aspek-aspek keterampilan proses, seperti keterampilan pengamatan, penafsiran, analisis, dst. Peneliti juga tidak mengamati peningkatan hasil belajar aspek afektif siswa. Untuk itu, pada penelitian berikutnya dapat dilakukan kajian mengenai hal tersebut melalui implementasi pendekatan keterampilan proses dalam jangka waktu yang relatif lebih lama, misalnya selama satu semeter penuh.

\section{DAFTAR PUSTAKA}

Arikunto, S. (2008). Dasar-dasar Evaluasi Pendidikan. Jakarta: Bumi Aksara.

Dimyati \& Mudjiono. (2009). Belajar dan Pembelajaran. Jakarta: Rineka Cipta.

Hendrik, P. S. (2000). Pembelajaran Konsep Struktur Tumbuhan dengan Menerapkan Pendekatan Keterampilan Proses untuk Meningkatkan Hasil Belajar Melalui Kegiatan Laboratorium. Tesis (Tidak Diterbitkan). UPI Bandung.

Kurniati, T. (2001). Pembelajaran Pendekatan Keterampilan Proses Untuk Meningkatkan Keterampilan Berpikir Kritis Siswa. Tesis PPS UPI. Bandung: Tidak diterbitkan

Memes, W. (2000). Model Pembelajaran Fisika di SMP. Jakarta: Proyek Pengembangan Guru Sekolah Menengah (PGSM) IBRD.

Memes, W. (2001). Dasar Evaluasi Pendidikan. Jakarta: Grafindo.

Rahayu, E., Susanto, H., \& Yulianti, D. (2011). Pembelajaran sains dengan pendekatan keterampilan proses untuk meningkatkan hasil belajar dan kemampuan berpikir kreatif siswa. Jurnal Pendidikan Fisika Indonesia (Indonesian Journal of Physics Education), 7 (2), 106-110.

Reviandari. (2008). Pembelajaran Berbasis Keterampilan Proses. http://edukasi.com. Diakses 12 Mei 2009.

Sanjaya, W. (2007). Strategi Pembelajaran Berorentasi Standar 
Proses Pendidikan. Jakarta: Sudarisman, S. (2010). Membangun Kencana Prenada Media Group.

Sardiman, S. (2005). Kurikulum dan Pengajaran. Jakarta: Bumi Aksara.

Semiawan, C. (1992). Pendekatan Keterampilan Proses. Jakarta: PT. Gramedia Widiasarana Indonesia.

Subagyo, Y., Wiyanto, \& Marwoto, P. (2009). Pembelajaran dengan Pendekatan Keterampilan Proses Sains untuk Meningkatkan Penguasaan Konsep Suhu dan Pemuaian. Jurnal Pendidikan Fisika Indonesia (Indonesian Journal of Physics Education), 5 (1), 42-46. Karakter Peserta Didik Melalui Pembelajaran Biologi Berbasis Keterampilan Proses. http://eprints.uns.ac.id Diakses 1 Januari 2010.

Wuryastuti, S. (2008). Inovasi pembelajaran IPA di sekolah dasar. Jurnal Pendidikan Dasar, 9, 1319. 